\title{
ANALISIS TIPE KESALAHAN BERDASARKAN TEORI NEWMAN DALAM MENYELESAIKAN SOAL CERITA PADA MATA KULIAH MATEMATIKA DISKRIT
}

\author{
Dwi Oktaviana \\ IKIP PGRI Pontianak \\ e-mail: dwi.oktaviana7@gmail.com
}

\begin{abstract}
Abstrak
Penelitian ini bertujuan untuk menganalisis kesalahan mahasiswa dalam mengerjakan soal cerita pada mata kuliah Matematika Diskrit menggunakan indikator kesalahan Newman. Penelitian ini menggunakan pendekatan kualitatif dan jenis penelitian adalah deskriptif. Subjek penelitian adalah mahasiswa Pendidikan Matematika kelas A Sore semester V IKIP PGRI Pontianak tahun akademik 2016/2017. Instrumen pada penelitian ini adalah soal tes yang dianalisis menggunakan indikator kesalahan Newman dan pedoman wawancara. Berdasarkan hasil analisis data diperoleh kesimpulan bahwa siswa melakukan (1) kesalahan membaca soal sebesar $24 \%$ berupa tidak mengetahui makna dari soal; (2) kesalahan memahami soal sebesar $24 \%$ berupa tidak mengetahui apa yang akan dicari; (3) kesalahan transformasi soal sebesar $54,67 \%$ berupa berupa tidak dapat membentuk fungsi pembangkit dari soal; (4) kesalahan keterampilan proses sebesar $88 \%$ berupa kesalahan dalam perhitungan; dan (5) kesalahan penulisan jawaban akhir sebesar $89,33 \%$ berupa kesalahan menuliskan jawaban akhir dari soal.
\end{abstract}

Kata Kunci: Analisis Kesalahan, Kategori Kesalahan Newman, Matematika Diskrit

\begin{abstract}
This research aims to analyze the students' mistakes in soving math essay-tests on the discrete Mathematics using Newman error category. This descriptive research used qualitative approach. The subjects of this research are the 7th semester students of math study program of IKIP PGRI Pontianak in academic year 2016/2017. The instrument of this research was the test items analized by Newman error category and interviews. Based on the results of data analysis it can be concluded that (1) $24 \%$ of reading errors were in form of not knowing the meaning, (2) $24 \%$ of comprehension error is not knowing what to look for (3) $54.67 \%$ of transformation error is in form of generating function of the problem (4) $88 \%$ of error processing skill is in form of errors in the calculation and (5) $89.33 \%$ of encoding error is in form of mistakes in making final answer of the test.
\end{abstract}

Keywords: discrete mathematics, error analysis, newman error categories

\section{PENDAHULUAN}

Objek kajian matematika berupa fakta, konsep, operasi, dan prinsip mempunyai karakter abstrak. Konsep-konsep abstrak itu merupakan salah satu dari hakikat matematika. Hudojo (2015) mengemukakan bahwa hakikat matematika berkenaan dengan ide-ide, struktur, dan hubungan-hubungannya yang diatur menurut urutan yang logis. Dalam matematika terdapat topik atau konsep prasyarat sebagai dasar untuk memahami topik atau konsep selanjutnya. Belajar matematika tidak hanya dituntut untuk menguasai 
konsep-konsep dalam matematika, tetapi mahasiswa juga dituntut untuk bisa mernerapkan konsep dalam pemecahan masalah sehari-hari. Pemecahan masalah dalam matematika biasanya diwujudkan melalui soal cerita. Menurut Abdurrahman (2010), alasan perlunya mempelajari matematika sebab matematika merupakan (1) sarana berpikir yang jelas dan logis, (2) sarana untuk memecahkan masalah kehidupan sehari-hari, (3) sarana mengenal pola-pola hubungan dan generalisasi pengalaman, (4) sarana untuk mengembangkan kreativitas, dan (5) sarana untuk meningkatkan kesadaran terhadap perkembangan budaya. Karena perannya yang sangat penting, sehingga matematika dipelajari sampai dengan jenjang pendidikan tinggi.

Matematika diskrit merupakan salah satu mata kuliah yang dipelajari di perguruan tinggi. Matematika diskrit adalah cabang ilmu matematika yang mempelajari tentang objekobjek diskrit dengan materi yang banyak, salah satunya adalah fungsi pembangkit. Fungsi Pembangkit adalah topik penting dalam Kombinatorik. Metode Fungsi pembangkit ini berakar dari karya De Mavre tahun 1720, dikembangkan oleh Euler dalam tahun 1746 untuk memecahkan masalah partisi, kemudian pada akhir dan awal abad 19 secara intensif dipakai oleh Laplace sehubungan dengan Teori Probabilitas (Roberts, 1984). Fungsi pembangkit dikembangkan untuk menangani batasan-batasan khusus dalam pemilihan dan permasalahan arangement (menyusun objek) dengan pengulangan. Fungsi pembangkit merupakan salah satu teknik pemecahan masalah yang paling abstrak yang diperkenalkan dalam matematika diskrit. Dalam mempelajari materi fungsi pembangkit ini banyak mahasiswa yang mengalami kesulitan dan kejenuhan dalam pemahaman dan menentukan penyelesaiannya. Salah satu permasalahan dalam menyelesaikan soal-soal fungsi pembangkit adalah soal matematika yang menggunakan kata-kata atau soal cerita (word problems).

Tahapan-tahapan analisis kesalahan yang sesuai dan yang dapat dilakukan pada bentuk soal cerita adalah tahapan analisis kesalahan menurut Newman (NEA). NEA adalah singkatan dari Newman's Error Analisis. NEA dirancang sebagai prosedur diagnostik sederhana dalam menyelesaikan soal cerita matematis (mathematical word problems). Newman (Clemen, 1980) mengemukakan bahwa jika siswa ingin menyelesaikan soal matematika dalam bentuk soal cerita maka siswa harus melalui lima langkah, yaitu meminta siswa untuk: (1) membaca soal (reading), (2) memahami masalah (comprehension), (3) transformasi (transformation), (4) keterampilan proses (process skill), dan (5) penulisan jawaban akhir (encoding).

Newman (Clemen, 1980) mengemukakan bahwa ketika siswa berusaha menjawab sebuah permasalahan yang berbentuk soal cerita, maka siswa tersebut telah melewati serangkaian rintangan berupa tahapan dalam pemecahan masalah, yang meliputi: a) Membaca masalah (Reading), ketika seseorang membaca sebuah teks, maka oleh 
pembaca akan direpresentasikan sesuai dengan pemahamannya terhadap apa yang dibacanya, atau dikenal sebagai hasi representasi dari kemampuan mental pembaca tersebut. Selanjutnya, kemampuan membaca siswa dalam menghadapi masalah berpengaruh terhadap bagaimana siswa tersebut akan memecahkan masalah; b) Memahami masalah (Comprehension), pada tahapan ini dikatakan mampu memahami masalah, jika siswa mengerti dari maksud semua kata yang digunakan dalam soal sehingga siswa mampu menyatakan soal cerita tersebut dengan kalimat sendiri. Pada tahapan ini siswa harus bisa menunjukkan ide masalah berbentuk soal cerita secara umum yang memuat "What, Why, Where, When, Who, dan How", dimana ide masalah dalam matematika tersebut direpresentasikan ke dalam unsur diketahui, ditanya dan prasyarat. Selanjutnya untuk mengecek kemampuan memahami masalah, siswa diminta menyebutkan apa saja yang diketahui dan ditanyakan dalam masalah; Transformasi masalah (Transformation), tahap ini, siswa mencoba mencari hubungan antara fakta (yang diketahui) dan yang ditanyakan. Selanjutnya untuk mengecek kemampuan mentransformasikan masalah yaitu mengubah bentuk soal cerita ke dalam bentuk matematikanya, siswa diminta menentukan metode, prosedur atau strategi apa yang akan digunakan dalam menyelesaikan soal; d) Keterampilan proses (Process Skill), pada tahap ini, siswa diminta mengimplementasikan rancangan rencana pemecahan masalah melalui tahapan transformasi masalah untuk menghasilkan sebuah solusi yang diinginkan. Pada tahapan ini yaitu untuk mengecek keterampilan memproses atau prosedur, siswa diminta menyelesaikan soal cerita sesuai dengan aturan-aturan matematika yang telah direncanakan pada tahapan mentransformasikan masalah; e) Penulisan jawaban (Encoding), pada tahapan ini, siswa dikatakan telah mencapai tahap penulisan jawaban apabila siswa dapat menuliskan jawaban yang ditanyakan secara tepat. Selanjutnya untuk mengecek kemampuan penulisan jawaban, siswa diminta melakukan pengecekkan kembali terhadap jawaban dan siswa diminta menginterpretasikan jawaban akhir. Adapun penelitian yang dilakukan oleh Miherda (2014) menunjukkan bahwa siswa mengalami kesalahan membaca (reading) sebanyak 50\%, kesalahan memahami soal (comprehension error) sebanyak 38,46\%, kesalahan keterampilan proses (processing error) sebanyak $3,85 \%$, dan kesalahan penulisan jawaban akhir (encoding error) sebanyak 7,69\%.

Peneliti bertujuan untuk menganalisis kesalahan mahasiswa dalam mengerjakan soal cerita pada mata kuliah Matematika Diskrit terutama dalam materi fungsi pembangkit menggunakan kategori kesalahan Newman. Diharapkan hasil penelitian ini dapat dijadikan dasar oleh dosen dalam memberikan bantuan secara tepat kepada siswa yang masih melakukan kesalahan dalam menyelesaikan soal cerita dalam mata kuliah Matematika Diskrit terutama pada materi fungsi pembangkit dan dapat dijadikan sebuah bahan refleksi 
untuk menentukan hal-hal apa saja yang harus ditekankan dalam mengajarkan mata kuliah Matematika Diskrit materi fungsi pembangkit.

\section{METODE}

Penelitian ini menggunakan penelitian deskriptif. Penelitian deskriptif bertujuan untuk memaparkan dan menggambarkan fakta-fakta berdasarkan cara pandang tertentu. Penelitian ini ditujukan untuk menganalisis kesalahan mahasiswa dalam mengerjakan soal cerita pada mata kuliah Matematika Diskrit menggunakan indikator kesalahan Newman mahasiswa semester V Program Studi Pendidikan Matematika IKIP PGRI Pontianak dalam mempelajari mata kuliah Matematika Diskrit.

Penelitian ini dilaksanakan di Program Studi Matematika IKIP PGRI Pontianak. Penentuan subjek penelitian dilakukan dengan menggunakan teknik purposive sampling. Adapun subjek penelitian adalah mahasiswa di kelas A Sore Program Studi Pendidikan Matematika. Teknik pengumpul data dalam penelitian teknik pengukuran dan teknik komunikasi langsung dengan alat pengumpul datanya berupa tes soal cerita terkait mata kuliah Matematika Diskrit khususnya materi Fungsi Pembangkit, dan pedoman wawancara berdasarkan Newman. Pada penelitian peneliti melakukan analisis kesalahan Newman terhadap hasil tes para mahasiswa yang terkait dengan materi Matematika Diskrit yaitu Fungsi Pembangkit dan untuk menganalisis kesalahan mahasiswa berdasarkan indikator kesalahan Newman (Clemen, 1980). Adapun indikator kesalahan Newman (Clemen, 1980) dapat dilihat pada Tabel 1. 
Tabel 1. Indikator Kesalahan Newman

\begin{tabular}{|c|c|c|}
\hline No & Jenis Kesalahan & Indikator \\
\hline 1 & $\begin{array}{l}\text { Kesalahan dalam } \\
\text { membaca soal (Reading } \\
\text { error) }\end{array}$ & $\begin{array}{l}\text { a. Mahasiswa salah dalam membaca istilah, symbol, } \\
\text { kata-kata atau informasi penting dalam soal. }\end{array}$ \\
\hline 2 & $\begin{array}{l}\text { Kesalahan dalam } \\
\text { memahami soal } \\
\text { (Comprehension error) }\end{array}$ & $\begin{array}{l}\text { a. Mahasiswa tidak mengetahui apa yang sebenarnya } \\
\text { ditanyakan pada soal. } \\
\text { b. Kesalahan menangkap informasi yang ada di soal } \\
\text { sehingga tidak dapat menyelesaikan ke proses } \\
\text { selanjutnya. }\end{array}$ \\
\hline 3 & $\begin{array}{l}\text { Kesalahan dalam } \\
\text { transformasi proses } \\
\text { (Transformation error) }\end{array}$ & $\begin{array}{l}\text { a. Mahasiswa gagal dalam mengubah ke bentuk model } \\
\text { matematika yang benar. } \\
\text { b. Mahasiswa salah dalam menggunakan tanda } \\
\text { operasi hitung untuk menyelesaikan soal. }\end{array}$ \\
\hline 4 & $\begin{array}{l}\text { Kesalahan dalam } \\
\text { keterampilan Proses } \\
\text { (Process Skill error) }\end{array}$ & $\begin{array}{l}\text { a. Mahasiswa salah dalam perhitungan atau } \\
\text { komputasi. } \\
\text { b. Mahasiswa tidak melanjutkan prosedur } \\
\text { penyelesaian. }\end{array}$ \\
\hline 5 & $\begin{array}{l}\text { Kesalahan dalam } \\
\text { menuliskan jawaban } \\
\text { akhir (Encoding error) }\end{array}$ & $\begin{array}{l}\text { a. Mahasiswa tidak dapat menuliskan jawaban akhir } \\
\text { yang diminta soal. } \\
\text { b. Mahasiswa tidak dapat menyimpulkan jawaban } \\
\text { sesuai kalimat matematika. } \\
\text { c. Kesalahan karena kecerobohan atau kurang cermat }\end{array}$ \\
\hline
\end{tabular}

Wawancara dilakukan untuk mendapatkan data tentang kesalahan-kesalahan yang dilakukan mahasiswa dalam menyelesaikan soal cerita. Teknik analisis data yang digunakann adalah reduksi data (data reduction), penyajian data (data display), dan penarikan kesimpulan (conclusion drawing).

\section{HASIL DAN PEMBAHASAN}

Analisis data dilakukan peneliti pada hasil tes mahasiswa dengan berpedoman pada indikator kesalahan Newman (Clemen, 1980), dengan mengidentifikasikan seberapa besar persentase untuk tiap-tiap soal pada masing-masing jenis kesalahan. Sebelumnya dianalisis hasil jawaban mahasiswa kelas A Sore Semester $\mathrm{V}$ untuk mata kuliah Matematika Diskrit diperoleh hasil pada Tabel 2.

Tabel 2. Hasil Jawaban Mahasiswa Per Soal

\begin{tabular}{ccccc}
\hline No Soal & Benar & Jawaban & $\begin{array}{c}\text { Tidak } \\
\text { Senjawab }\end{array}$ & Total \\
\hline 1 & 6 & 19 & 0 & 25 \\
2 & 1 & 22 & 2 & 25 \\
3 & 1 & 22 & 2 & 25 \\
\hline Jumlah & 8 & 63 & 4 & 75 \\
\hline Persentase & $10,67 \%$ & $84 \%$ & $5,33 \%$ & $100 \%$ \\
\hline
\end{tabular}


Tabel 2 menunjukkan bahwa mahasiswa yang tidak melakukan kesalahan sebesar 10,67\% sedangkan mahasiswa yang melakukan kesalahan sebesar $89,33 \%$ dengan menjawab salah sebesar $84 \%$ dan tidak menjawab soal sebesar $5,33 \%$.

Selanjutnya dianalisis mahasiswa yang melakukan kesalahan berdasarkan indikator Newman. Adapun rekapitulasi persentase hasil analisis terhadap jawaban mahasiswa dapat dilihat pada Tabel 3.

Tabel 3. Rekapitulasi Persentase Kesalahan Mahasiswa Berdasarkan Indikator Newman

\begin{tabular}{llccccccc}
\hline No & Jenis Kesalahan & $\begin{array}{c}\text { Soal } \\
\text { No 1 }\end{array}$ & $\%$ & $\begin{array}{c}\text { Soal } \\
\text { No 2 }\end{array}$ & $\%$ & $\begin{array}{c}\text { Soal } \\
\text { No 3 }\end{array}$ & $\begin{array}{c}\text { \% } \\
\begin{array}{c}\text { Rata- } \\
\text { rata }\end{array}\end{array}$ \\
\hline 1 & Membaca Soal & 8 & 32 & 2 & 8 & 8 & 32 & 24 \\
2 & Memahami Soal & 8 & 32 & 2 & 8 & 8 & 32 & 24 \\
3 & Mentransformasikan & 15 & 60 & 4 & 16 & 22 & 88 & 54,67 \\
4 & $\begin{array}{l}\text { Keterampilan } \\
\text { Proses }\end{array}$ & 18 & 72 & 24 & 96 & 24 & 96 & 88 \\
5 & $\begin{array}{l}\text { Penuliskan } \\
\text { Jawaban Akhir }\end{array}$ & 19 & 76 & 24 & 96 & 24 & 96 & 89,33 \\
\hline
\end{tabular}

Tabel 3 menunjukkan bahwa soal nomor 1 berkaitan dengan mencari koefisien dari suatu fungsi pembangkit, soal nomor 2 berkaitan dengan fungsi pembangkit pada permasalahan kombinasi, soal nomor 3 berkaitan dengan fungsi pembangkit pada permasalahan permutasi, dan terlihat bahwa paling banyak kesalahan yang dialami mahasiswa terjadi pada tahap penulisan jawaban akhir dengan rata-rata persentase sebesar $89,33 \%$. Hal ini berkaitan dengan mentransformasikan dan ketrampilan proses. Apabila mahasiswa tidak dapat mentransformasikan soal dan tidak tepat dalam proses pengerjaannya, maka pasti akan salah pada tahap penulisan jawaban akhirnya.

Dari kesalahan yang dilakukan mahasiswa, selanjutnya peneliti akan membahas hasil wawancara berdasarkan kesalahan-kesalahan mahasiswa tersebut. Berdasarkan hasil wawancara yang telah dilakukan oleh peneliti kepada mahasiswa pada tiap butir soalnya, diperoleh faktor-faktor yang menyebabkan kesalahan yang dialami mahasiswa dalam mengerjakan soal cerita fungsi pembangkit baik kesalahan membaca soal, memahami soal, mentransformasikan, ketrampilan proses dan penulisan jawaban akhir dari setiap subjek pada setiap butir soal.

Hasil analisis data menunjukkan bahwa rata-rata persentase pada kesalahan dalam membaca soal sebesar $24 \%$. Berikut adalah hasil pekerjaan mahasiswa yang menyelesaikan soal yang melakukan kesalahan dalam membaca soal dapat dilihat dari Gambar 1. 




Gambar 1. Hasil pekerjaan mahasiswa pertama

Gambar 1 menunjukkan bahwa pekerjaan mahasiswa kesalahan yang terjadi dikarenakan mahasiswa tidak mengetahui informasi penting dalam soal. Ketika menuliskan persamaan fungsi pengbangkit terlihat mahasiswa hanya menuliskan ulang apa yang terdapat di soal sehingga untuk melanjutkan penyelesaian mahasiswa mengalami kebingungan dan tidak dapat menyelesaikan soal. Hal ini sesuai dengan pernyataan Clemen (1980) tentang kemampuan mahasiswa dalam membaca akan mempengaruhi cara memecahkan masalah. Oleh karena itu, mahasiswa tidak dapat menjawab soal dengan benar. Hasil analisis wawancara ke beberapa mahasiswa diperoleh data bahwa mahasiswa melakukan kesalahan membaca soal karena tidak mengetahui makna dari soal yang akan dikerjakan dan bingung pada saat mengerjakan.

Rata-rata persentase kesalahan dalam memahami soal setelah dianalisis sebesar $24 \%$. Berikut adalah hasil pekerjaan mahasiswa yang menyelesaikan soal yang melakukan kesalahan dalam membaca soal dapat dilihat dari Gambar 2.



Gambar 2. Hasil pekerjaan mahasiswa kedua

Gambar 2 menunjukkan bahwa dari hasil pekerjaan mahasiswa kesalahan yang terjadi dikarenakan mahasiswa tidak mengetahui apa yang ditanya di soal. Pada soal diminta ditanyakan menyusun kata kunci dengan syarat huruf konsonan harus muncul sehingga terjadi pemisahan antara huruf vocal dan huruf konsonan namun mahasiswa 
dalam memisahkan antara huruf vocal dan huruf konsonan masih mengalami kesalahan sehingga mahasiswa mengalami kebingungan dalam menyelesaikan soal. Hal ini sesuai dengan pernyataan Prakitipong dan Nakamura (2006:114), mahasiswa dikatakan telah mencapai tahap memahami apabila mahasiswa dapat menjelaskan apa permasalahannya. Pada tahap ini mahasiswa dapat memahami konteks masalah yang diberikan dan mengetahui apa yang diberikan dan mengetahui apa yang akan dicarinya. Hasil analisis wawancara ke beberapa mahasiswa menunjukkan bahwa mahasiswa melakukan kesalahan memahami soal dikarenakan mahasiswa tidak mengetahui maksud kalimat yang terdapat pada soal sehingga tidak mengetahui apa yang akan dicari.

Rata-rata persentase pada kesalahan dalam mentransformasikan setelah dianalisis sebesar 54,67\%. Kesalahan ini merupakan kesalahan yang sering dilakukan oleh mahasiswa dalam menyelesaikan soal cerita pada mata kuliah Matematika Diskrit sehingga pada proses selanjutnya mahasiswa mengalami kesalahan. Berikut adalah hasil pekerjaan mahasiswa yang menyelesaikan soal yang melakukan kesalahan dalam membaca soal dapat dilihat dari Gambar 3.

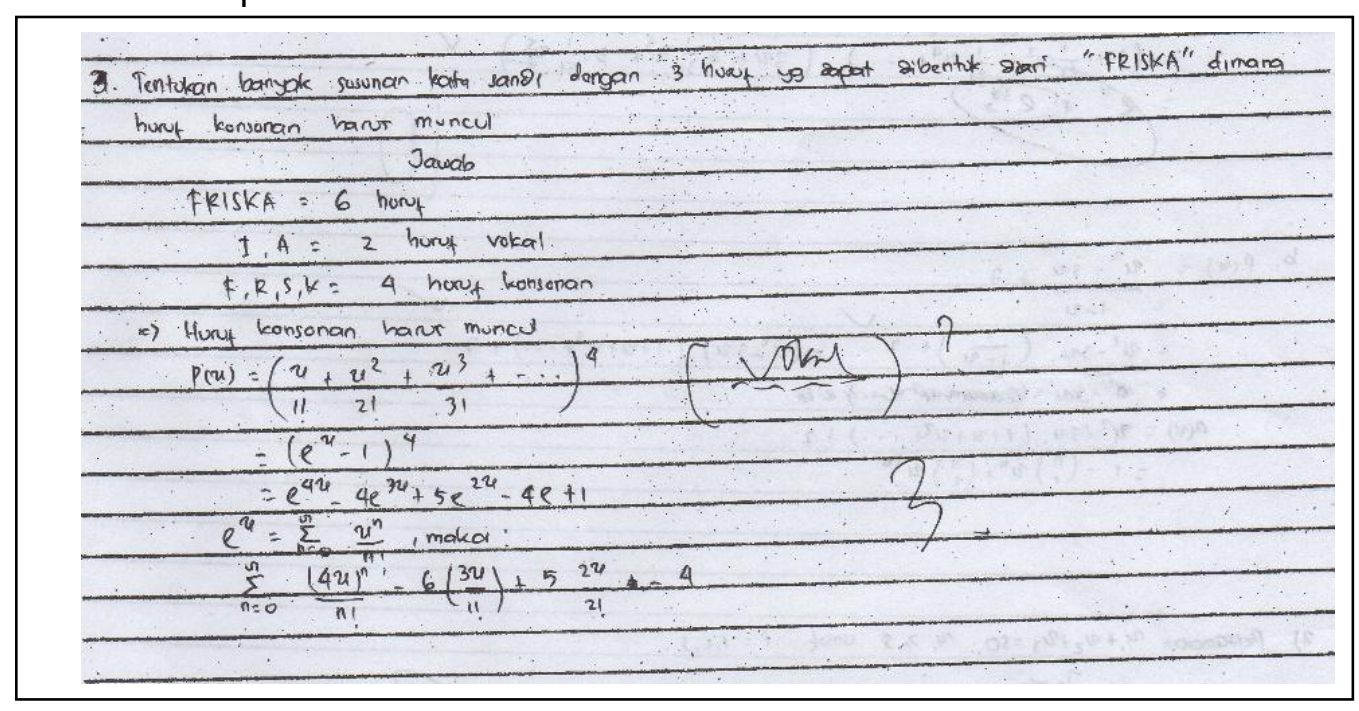

Gambar 3. Hasil pekerjaan mahasiswa ketiga

Gambar 3 menunjukkan bahwa hasil pekerjaan mahasiswa kesalahan yang terjadi dikarenakan mahasiswa gagal dalam mengubah ke bentuk model matematika yang benar. Mahasiswa mengalami kesalahan ketika mengubah soal cerita terkait permasalahan permutasi ke persamaan fungsi pembangkit padahal sebelumnya mahasiswa sudah mengerti memisahkan huruf yang tersedia ke dalam huruf konsonan dan huruf vocal namun dalam membentuk persamaan fungsi pembangkit mahasiswa mengabaikan huruf vocal sehingga persamaan yang dibentuk bukan $P(x)=\left(\frac{x}{1 !}+\frac{x^{2}}{2 !}+\frac{x^{3}}{3 !}+\cdots\right)^{4}$ seharusnya $P(x)=\left(\frac{x}{1 !}+\frac{x^{2}}{2 !}+\frac{x^{g}}{3 !}+\cdots\right)^{4}\left(1+\frac{x}{1 !}+\frac{x^{2}}{2 !}+\cdots\right)^{2} \quad$ sehingga ke proses berikutnya 
mahasiswa mengalami kesalahan dalam menjawab soal dan juga mengalami kesalahan terhadap penulisan jawaban akhir. Tahapan transformasi (transformation) ini merupakan tahapan yang sangat penting dalam menyelesaikan soal pada mata kuliah Matematika Diskrit sehingga jika mahasiswa tidak dapat membuat persamaan fungsi pembangkit dengan benar maka mahasiswa tidak dapat menyelesaikan soal yang diberikan. Hal ini sesuai dengan penelitian yang dilakukan Prakitipong dan Nakamura (2006:114) yang menyatakan tahapan transformasi (transformation) sangat penting dalam menyelesaikan soal SPLDV. Siswa telah mencapai tahap transformasi ketika siswa dapat memilih metode yang digunakan dan dapat menyusun persamaan-persamaan linear dua variabel yang sesuai dengan soal, sehingga kesalahan transformasi (transformation) terjadi jika siswa tidak dapat menentukan metode apa yang digunakan dan tidak dapat menyusun persamaan linear dua variabel sesuai dengan keterangan dalam soal. Berdasarkan hasil analisis wawancara ke beberapa mahasiswa menunjukkan bahwa mahasiswa melakukan kesalahan mentransformasikan dikarenakan mahasiswa tidak dapat membentuk fungsi pembangkit dari soal cerita yang diberikan.

Rata-rata persentase pada kesalahan dalam keterampilan proses (process skill error) setelah dianalisis sebesar $88 \%$. Berikut adalah hasil pekerjaan mahasiswa yang menyelesaikan soal yang melakukan kesalahan dalam membaca soal dapat dilihat dari Gambar 4.

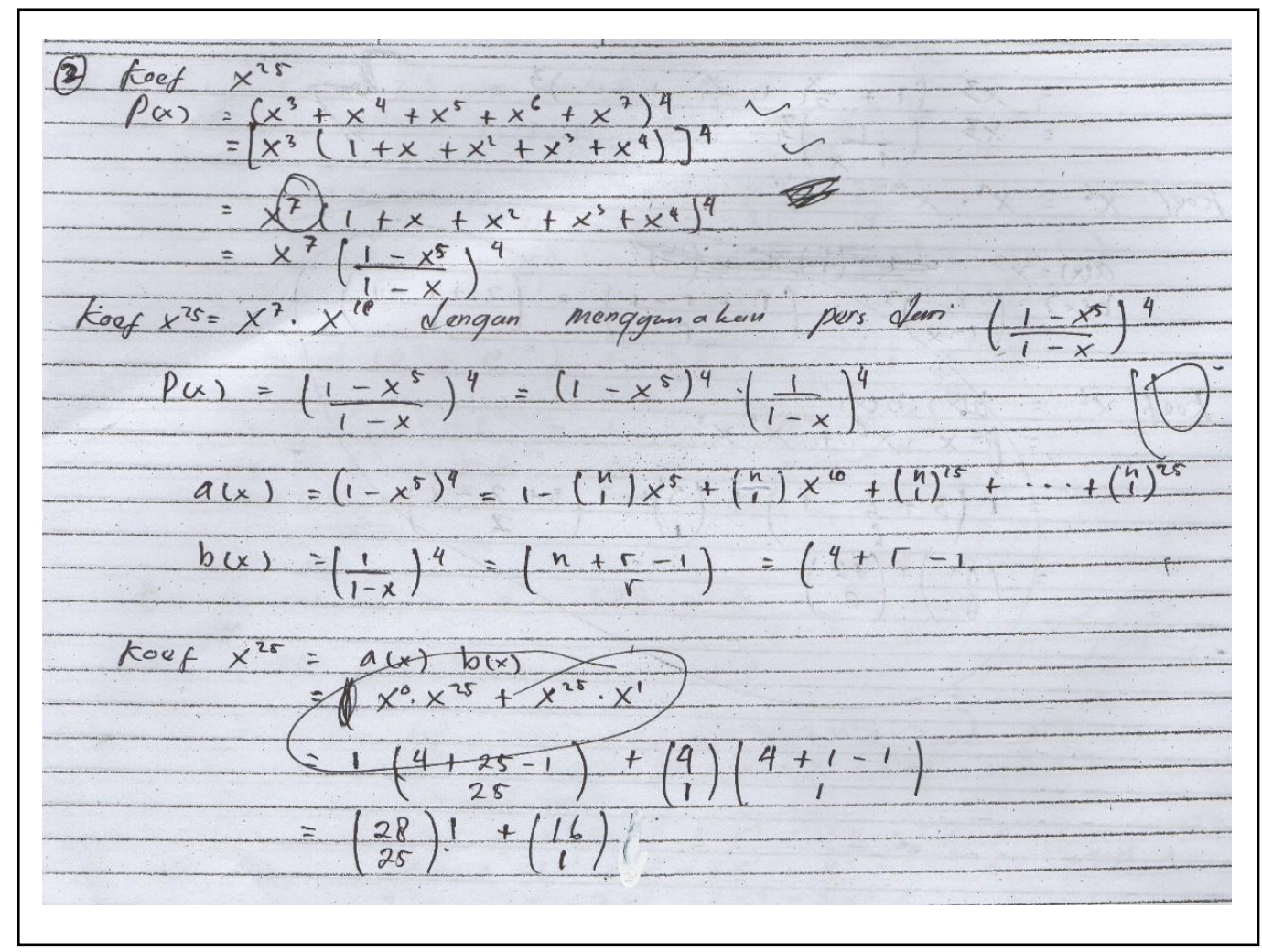

Gambar 4. Hasil pekerjaan mahasiswa keempat 
Gambar 4 menunjukkan bahwa pekerjaan mahasiswa kesalahan yang terjadi dikarenakan mahasiswa salah dalam perhitungan dan tidak menyelesaikan prosedur penyelesaian. Mahasiswa telah benar sampai proses mentransformasikan yaitu membentuk persamaan fungsi pembangkit yang diminta pada soal namun pada saat proses perhitungan mahasiswa melakukan kesalahan yaitu ketika melakukan pemangkatan seharusnya dikalikan namun mahasiswa melakukan perhitungan dengan menjumlahkan yaitu $x^{7}\left(1+x+x^{2}+x^{3}+x^{4}\right)^{4}$ seharusnya $x^{12}\left(1+x+x^{2}+x^{3}+x^{4}\right)^{4}$ sehingga ke proses penulisan jawaban akhir juga mengalami kesalahan. Dari hasil analisis wawancara dengan beberapa mahasiswa menunjukkan bahwa mahasiswa melakukan kesalahan keterampilan proses dikarenakan mahasiswa kurang teliti dalam proses perhitungan dan tergesa-gesa dalam mengerjakan soal.

Rata-rata persentase pada kesalahan dalam menuliskan jawaban akhir (encoding error) setelah dianalisis persentase sebesar $89,33 \%$. Kesalahan dalam menuliskan jawaban akhir merupakan kesalahan yang paling banyak kesalahan yang dialami mahasiswa. Hal ini sejalan dengan penelitian yang dilakukan oleh Mulyadi (2015: 380) yang menyatakan bahwa pada kemampuan spasial tinggi, sedang, dan rendah kesalahan terbesar adalah kesalahan transformasi dan kesalahan kesimpulan. Berikut adalah hasil pekerjaan mahasiswa yang menyelesaikan soal yang melakukan kesalahan dalam membaca soal dapat dilihat dari Gambar 5.

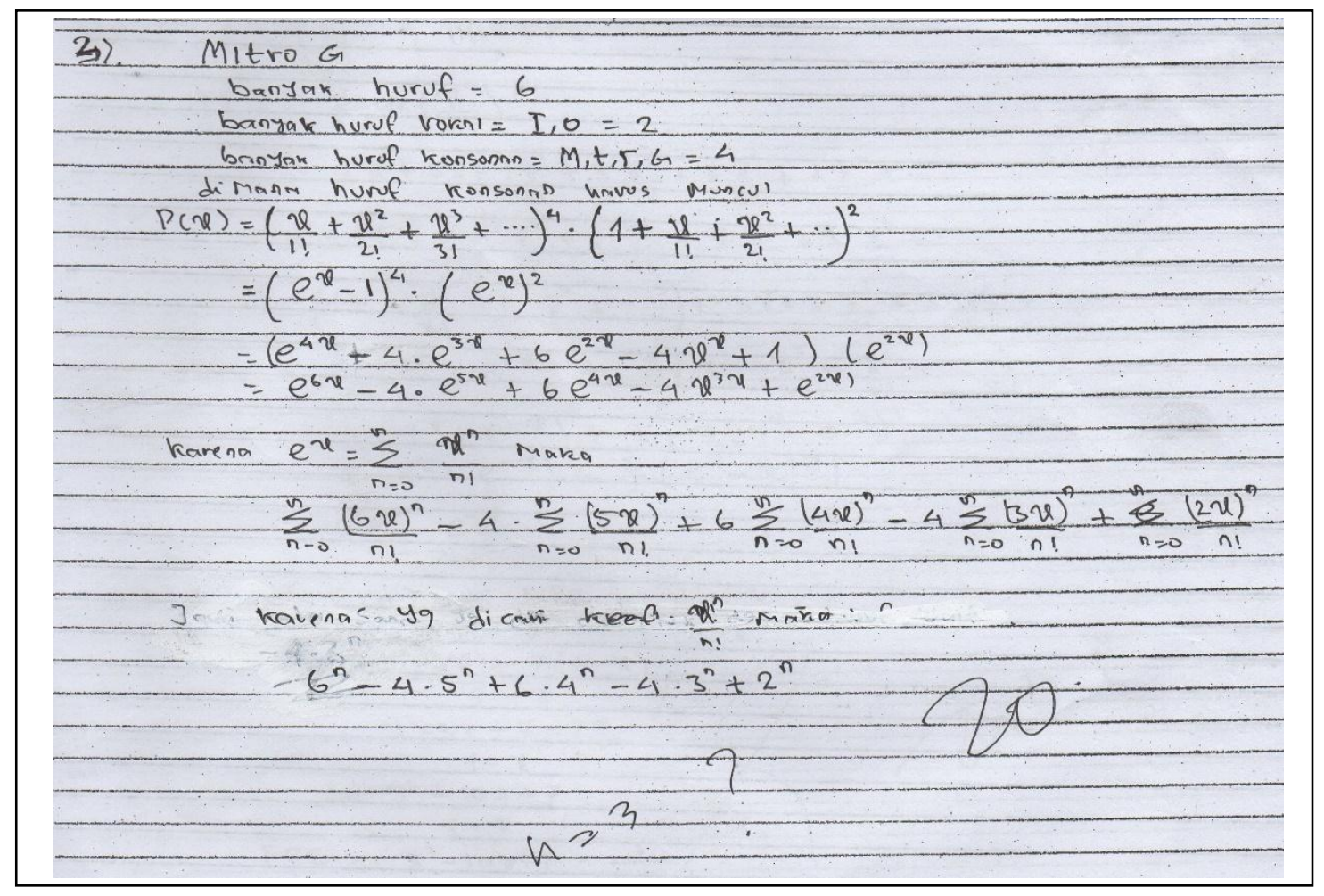

Gambar 5. Hasil Pekerjaan Mahasiswa Kelima

Gambar 5 menunjukkan bahwa pekerjaan mahasiswa kesalahan yang terjadi dikarenakan ada mahasiswa yang menuliskan jawaban akhir yang tidak sesuai. 
Pertanyaan yang diminta adalah menyusun kata sandi dengan 3 huruf namun mahasiswa tidak melengkapi jawaban dengan memasukkan nilai $n=3$ sehingga penulisan jawaban akhir mahasiswa terjadi kesalahan walaupun mahasiswa sudah benar mencari solusi dari banyaknya susunan yang dibentuk. Hasil analisis wawancara dengan beberapa mahasiswa menunjukkan bahwa mahasiswa melakukan kesalahan menuliskan jawaban akhir dikarenakan mahasiswa kurang teliti dalam penulisan jawaban akhir.

\section{SIMPULAN}

Kesalahan dalam membaca soal yang dilakukan mahasiswa berupa tidak mengetahui kata kunci/makna dari soal dengan persentase sebesar $24 \%$; kesalahan dalam memahami soal yang dilakukan mahasiswa berupa tidak mengetahui apa yang akan dicari dengan persentase sebesar $24 \%$; kesalahan dalam mentransformasikan yang dilakukan mahasiswa berupa tidak dapat membentuk fungsi pembangkit dari soal cerita yang diberikan dengan persentase sebesar 54,67\%; kesalahan dalam keterampilan proses yang dilakukan mahasiswa berupa kesalahan dalam perhitungan dengan persentase sebesar $88 \%$; dan kesalahan dalam penulisan jawaban akhir yang dilakukan mahasiswa berupa kesalahan menuliskan jawaban akhir dari soal dengan persentase sebesar $89,33 \%$.

\section{DAFTAR PUSTAKA}

Abdurrahman, M. 2010. Pendidikan bagi anak berkesulitan belajar. Jakarta: PT. Rineka Cipta.

Clemen, M. N. 1980. The Newman Procedure For Analysing Errors On Written Mathematical Tasks. Educational Studies in Mathematics

Hudojo, H. 2005. Pengembangan Kurikulum dan Pembelajaran Matematika. Malang: Universitas Negeri Malang Press.

Miherda, P. 2014. Analisis Kesalahan Soal Cerita Pokok Bahasan Sistem Persamaan Linier Dua Variabel Berdasarkan Tahapan Newman Pada Kelas $X$ di SMK Diponegoro Salatiga Tahun Ajaran 2013/2014. Skripsi: UKSW

Mulyadi, M., Riyadi, R., \& Subanti, S. 2015. Analisis Kesalahan Dalam Menyelesaikan Soal Cerita Pada Materi Luas Permukaan Bangun Ruang Berdasarkan Newman's Error Analysis (Nea) Ditinjau Dari Kemampuan Spasial. Jurnal Elektronik Pembelajaran Matematika, 3(4): 370-382.

Prakitipong, N. \& Nakamura, S. 2006. Analysis of Mathematics Performance of Grade Five Students in Thailand Using Newman Prosedure. Journal of International Cooperative Education. 9(1): 111-122.

Roberts, F. S. 1984. Applied Combinatorics. Prentice Hall Inc., New Jersey, USA. 